\title{
脊髄くも膜囊腫の手術成績
}

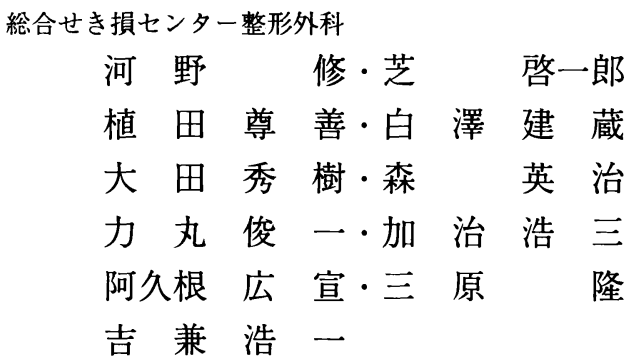

\section{Surgical Treatment for Spinal Arachnoid Cyst}

by

Osamu Kawano, Keiichiro Shiba, Takayoshi Ueta, Kenzo Shirasawa, Hideki Ohta, Eiji Mori, Shun-ichi Rikimaru, Kozo Kaji, Hironobu Akune, Takashi Mihara and Koichi Yoshikane

Department of Orthopaedic Surgery, Spinal Injuries Center, Fukuoka, Japan

We evaluated the operative results in 7 cases of spinal arachnoid cyst. 6 cases had intradural arachnoid cysts, and one was extradural. No cases had a history of trauma and all were located on the dorsal side of the spinal cord. All cases were treated by laminectomy and partial resection of the arachnoid cyst. At post-operative follow-up all cases were good or fair, with no excellent or poor cases.

Spinal arachnoid cyst is a slowly progressive disease with spinal cord atrophy, making it difficult to obtain excellent results by surgical treatment. Spinal arachnoid cysts should be diagnosed and treated surgically as soon as possible.

Key words : spinal arachnoid cyst（脊䯣くも膜襄腫）, surgical treatment（観血的治療）, myelopathy (脊㖪症), spinal cord atrophy（脊䯣萎縮）

$$
\text { はじめに }
$$

脊髄くも膜襄腫は, 1903 年 Spiller ${ }^{10)}$ により初めて 報告された比較的稀な疾患で, 硬膜内くも膜囊腫は脊 髄腫瘍の $3 \%$, 硬膜外くも膜衰腫は $1 \%$ 程度である といわれている. 今回我々は, 硬膜内くも膜囊腫 6 例, 硬膜外くも膜囊腫 1 例の手術治療例を経験したので, その手術成績について報告し, 診断や病態について文 献と比較しながら考察を加えた。

\section{対象および方法}

対象は 1983 年 7 月から 1994 年 12 月までに当セン ターにて手術施行した脊鹃くも膜襄腫 7 例（硬膜内 6 例，硬膜外 1 例). 男 3 例女 4 例で，手術時平均年齢 は 55 歳（38～68 歳）であった。亭腫は $\mathrm{T} 5$ ～T7 と中 位胸椎に好発し, 襄腫の上下の広がりは平均 4 椎体ほ どであった。手術後の平均経過観察期間は 4 年 10 力 月（ 4 カ月〜 12 年）であった.

手術成績の評価法としては, 術前の症状がほとんど 消失したものを著明改善とし, 程度の差はともかく自 
他覚ともに症状の改善が見られたものを中等度改善, しびれが軽くなったとか歩きやすくなったという傾向 はあるものの症状改善が非常に小さい場合は軽度改善 とし, 症状不変, 症状悪化を加え 5 段階で評価した.

\section{結果}

手術時年齢は平均 55 歳であり中高年での手術施行 であった，症状発現に際し外傷歴を有するものは一例 もなかった．初発症状と思われる時期から手術までの 経過は 10 カ月〜 10 年であり非常に緩徐な経過をとる ものが多かった．背部痛など局所の疼痛で発症するこ

表 1 症例のまとめ (1)

\begin{tabular}{rrrrrrrr}
\hline \hline case & $\begin{array}{c}\text { age } \\
\text { sex }\end{array}$ & 外傷 & 経過 & 背部痛 & 麻痷 & 症状変動 膀胱障害 \\
\hline 1 & $61 \mathrm{~F}$ & - & $1 \mathrm{y}$ & - & + & + & + \\
2 & $68 \mathrm{~F}$ & - & $10 \mathrm{~m}$ & + & - & + & + \\
3 & $38 \mathrm{M}$ & & $10 \mathrm{y}$ & - & + & + & - \\
4 & $57 \mathrm{~F}$ & - & $3 \mathrm{y} 4 \mathrm{~m}$ & + & - & + & - \\
5 & $64 \mathrm{M}$ & - & $7 \mathrm{y}$ & - & + & + & + \\
6 & $43 \mathrm{~F}$ & - & $1 \mathrm{y}$ & + & + & + & + \\
7 & $51 \mathrm{M}$ & - & $5 \mathrm{y}$ & + & + & + & + \\
\hline
\end{tabular}

とが多いという報告があるが 7 例中 4 例に背部痛を認 めた。症状は Myelopathy あるいは痙性麻痺であり， 咳や体位変換などによる症状増悪 ${ }^{6) 9}$ や，経過におけ る一時的な症状の軽快増悪など何らかの症状変動は全 例に認められた（表 1)。囊腫は 1 例が硬膜外であり， 硬膜内の 6 例については囊腫は瓷髄よりも背側に存在 した. 手術においては全例に椎弓切除術と囊腫瘍部分 切除術を行った。病理組織学的診断において囊腫壁は くも膜組織からなることを全例で確認した. 手術後の 経過観察時に MRI あるいは CTM を施行したのは 4 例有りそれら全例に関しては，脊䯙の圧迫はとれてい

表 2 症例のまとめ $(2)$

\begin{tabular}{|c|c|c|c|c|c|}
\hline case & & ation & follow & $\begin{array}{c}\text { cord } \\
\text { atrophy }\end{array}$ & 症状改善 \\
\hline 1 & $\mathrm{~T} 5 \sim 6$ & 硬膜内背側 & $3 \mathrm{y} 10 \mathrm{~m}$ & + & 中等度 \\
\hline 2 & $\mathrm{~T} 4 \sim 9$ & 硬膜内背側 & $4 \mathrm{~m}$ & + & 中等度 \\
\hline 3 & $\mathrm{~T} 6 \sim 12$ & 硬膜内背側 & $3 y$ & + & 中等度 \\
\hline 4 & $\mathrm{~T} 5 \sim 7$ & 硬膜内背側 & $5 \mathrm{~m}$ & + & 軽 度 \\
\hline 5 & $\mathrm{~T} 6 \sim 11$ & 硬膜内背側 & $12 \mathrm{y}$ & $?$ & 不 変 \\
\hline 6 & $\mathrm{~T} 4 \sim 5$ & 硬膜内背側 & $9 y$ & $?$ & 不 変 \\
\hline 7 & $\mathrm{~L} 1 \sim 2$ & 硬膜外 & $5 \mathrm{y} 6 \mathrm{~m}$ & $?$ & 軽 度 \\
\hline
\end{tabular}

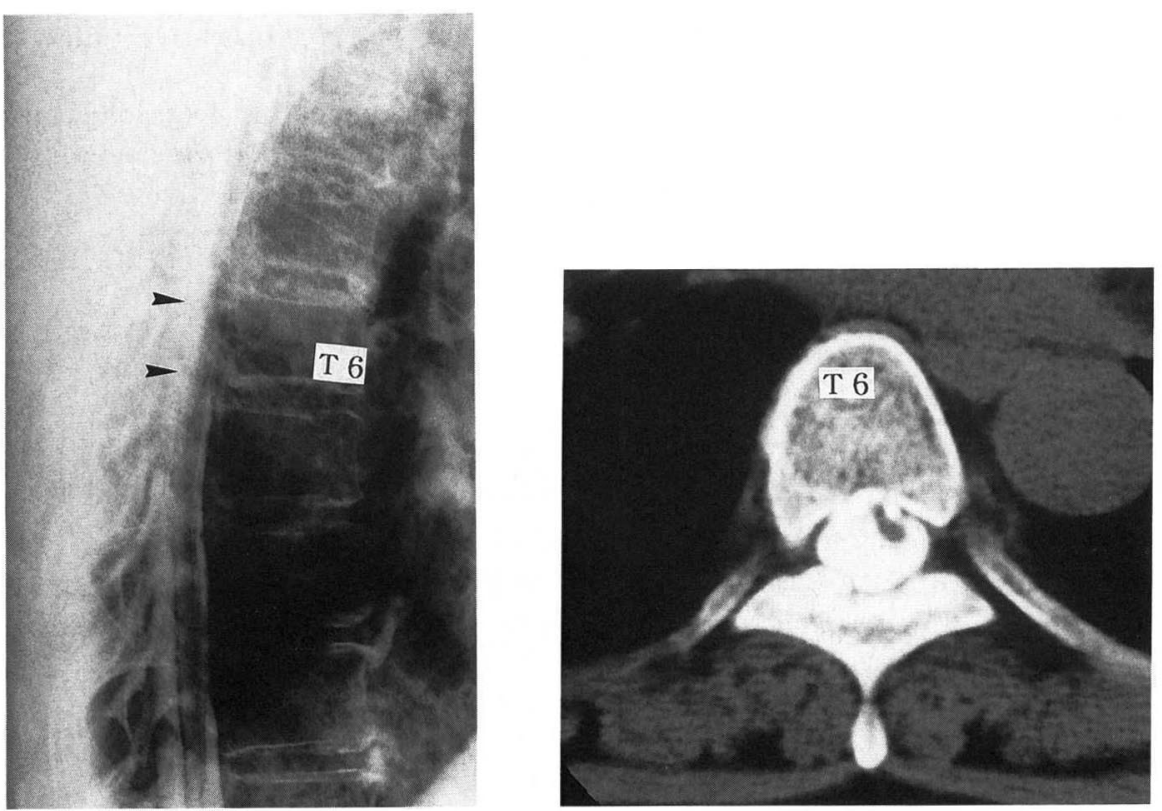

図 1 術前 Myelography と CTM 造影剂の貯留は 3 椎体に及び, 脊骾は右後方から圧迫を受けている 

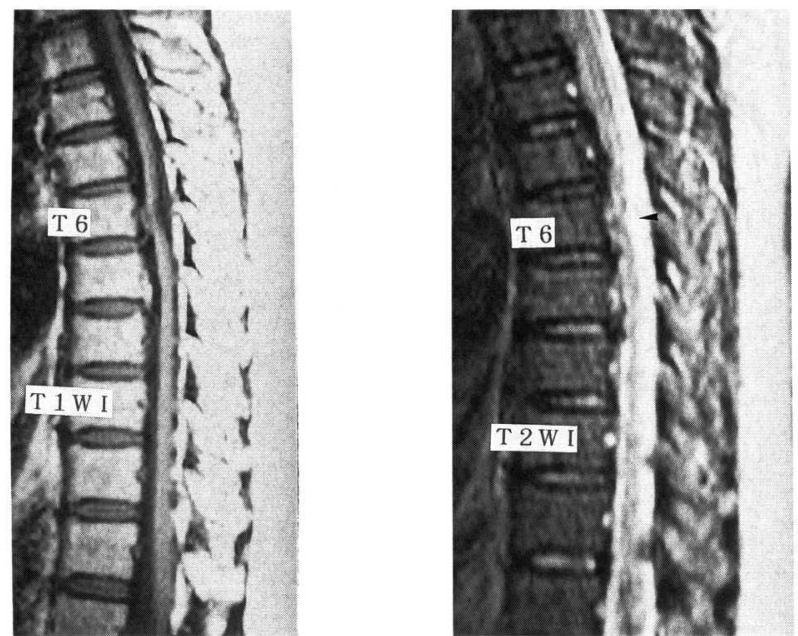

図 2 術前 MRI

$\mathrm{T} 1$ 強調像にて脊髄は後方から圧迫されており， $\mathrm{T} 2$ 強調像にて襄腫は 髄液よりやや高輝度に描出される

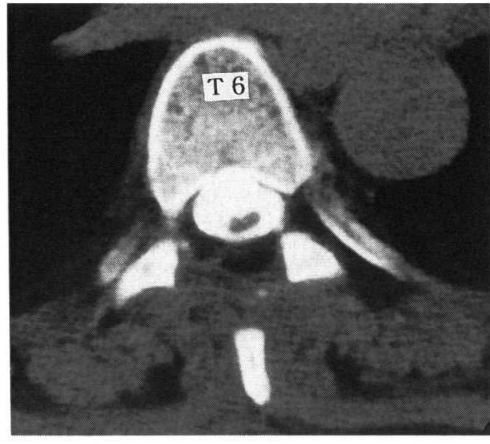

図 3 術後 CTM

後方からの圧迫はないが猆髄萎縮は著明である

たものの脊髄萎縮もみられた。この際脊髄横径がくも 膜下腔の $50 \%$ 以下のものを脊髄萎縮とした ${ }^{13)}$. 症状 改善は中等度改善が 3 例, 軽度改善が 2 例, 不変例が 2 例であった（表 2 ).

\section{症例}

Case 4. 57 歳, 女性. 主訴は歩行障害と下肢のし びれ，および背部から側胸部の違和感. 術前ミエログ ラムでは第 6 胸椎を中心に硬膜内背側における造影剂 の貯留が 3 椎体におよび, CTM では正常な形態と思 われる硬膜内に扔いて，脊䯣が後方からの造影剂貯留

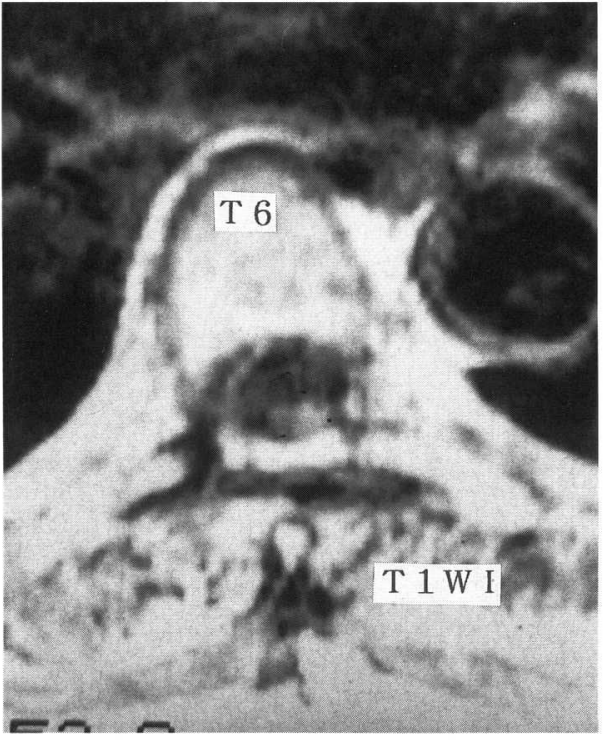

図 4 術後 5 カ月の MRI

囊腫の再発はないが, 脊䯣萎縮は残存する

により圧迫を受け，高度に扁平化していた（図 1）。 MRI において囊腫は T2 強調像で䯣液よりもやや高 輝度に描出された（図 2). 術中所見では，硬膜をあ けると二相性の拍動すなわち通常の呼吸性拍動に若干 遅れて囊腫の拍動が見られ，囊腫壁はやや白濁してい 

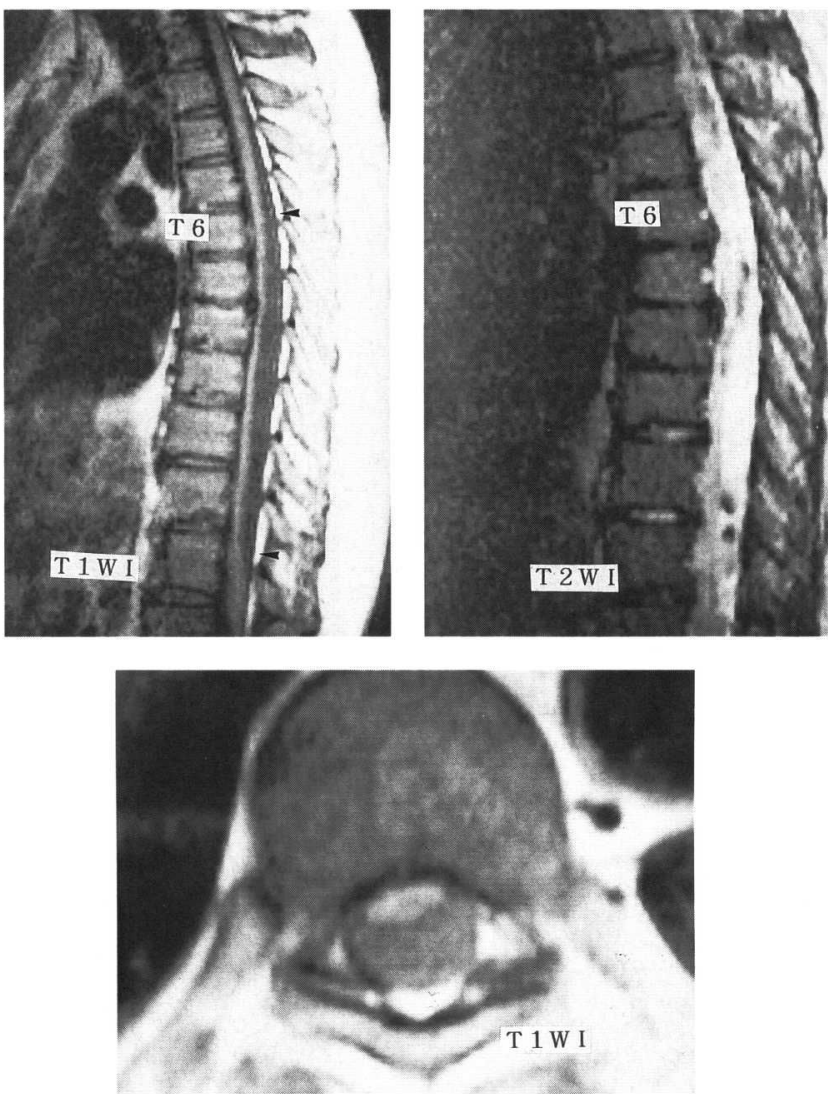

図 5 術前 MRI

襄腫は Th6 127 椎体に及び, 硬膜内背側に存在する

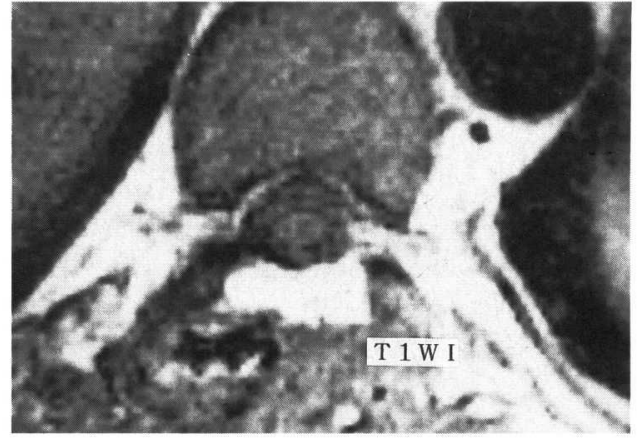

図 6 術後 MRI

脊䯣の圧迫はないものの，春䯣萎縮が見られる
た. 囊腫の全摘は不可能で部分切除を行うにとどまっ た，術後のミエログラムと CTM では，脊髄の後方か らの圧迫は全くないものの春髄の萎縮は著明であった (図 3). 手術後 5 力月目の MRI では, 囊腫の再発は 見られないが春髄の萎縮は著明である（図 4). 症状 はしびれが少し軽くなった程度の軽度改善であった。

Case 3. 38 歳, 男性. 主訴は歩行障害と下肢のし びれ，脱力. 10 年前から咳をすると下肢がしびれて いた，術前の MRI では, 囊腫は硬膜内背側に第 6 胸 椎から第 12 胸椎まで約 7 椎体におよぶ大きさであっ た（図 5)。手術後 1 力月目の MRI では, 春䯣の圧迫 はとれているものの脊髄の萎縮は存在した（図 6). 手術後 3 年目の MRI では, 囊腫の再発は見られない. 泰䯣は若干膨らんだように見えるが正常の太さではな い（図 7)。症状はしびれの軽隇と下肢筋力増強が見 


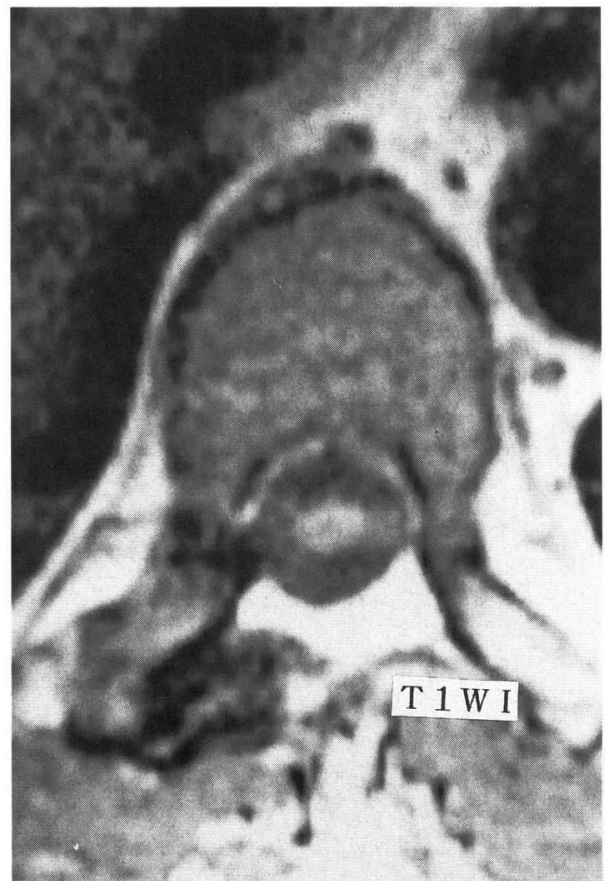

図 7 術後 3 年の MRI

襄腫の再発はないが脊髄萎縮はある

られ中等度改善であった。

考察

髄膜より発生する囊腫については様々な分類がある が, Nabors ${ }^{5)}$ は 3 型に分類した。すなわち type 1; extradural meningial cysts without spinal nerve root fibers, type 2; extradural meningial cysts with spinal nerve root fibers, type 3 ; spinal intradural meningial cystsである。こ の分類に従えば今回の症例のうち 6 例は Type 3,1 例は夕イプ 2 に分類される. 成因としては先天説 ${ }^{8)}$, 炎症説 ${ }^{11}$, 外傷説 ${ }^{91}$ などがあげられるが, 今回の症例 で明らかな外傷歴を有するものは 1 例もなかった。

Perret ( $^{8)}$ は, 脊髄背側くも膜下腔の septum posticum からの発生を主張したが, 今回は全例にお いて囊腫は脊髄背側に存在したことや術中所見で囊腫 壁が癒着していたり白濁していたりした症例が多かっ たことから，先天性に存在するものに何らかの炎症が 加わることにより神経症状を出現させるような囊腫が 形成されるものと思われる。
診断には CTM および MRI が有効であると思われ る. CTMでは, ほぼ正常な硬膜内に前方へ偏位し萎

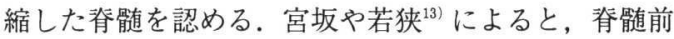
後径がくも膜下腔の $50 \%$ 以下の場合，春髄萎縮陽性 としている．MRIにおいてくも膜囊腫は脳脊䯣液の 拍動の影響により T2 強調像で高輝度を呈するという 報告 ${ }^{2)} や ，$ 脳脊髄液の乱流による flow-void signに より低輝度を呈するという報告 ${ }^{12)}$ があるが, 我々の症 例では囊腫は高輝度を呈した。ミエログラムでは水溶 性造影剂と脳脊䯣液との親和性が高いことから囊腫状 陰影を得て診断をすることは困難であると思われる。 前沢ら ${ }^{3)}$ は咳や体位変換などで症状の変動が見られる ことからミエログラムにおいて様々な体位での撮影や バルサルバ手技の試みなども必要であると指摘してい る.

術式に関しては, 囊腫壁のわずかな損傷で囊腫は収 縮してしまうためシャント術は不可能であり全摘も不 可能であるため全例部分切除にとどまったが，追跡し 得た範囲での囊腫の再発はないので部分切除で充分で あると考えている。

手術成績は, 症状の著明改善例はなく, 中等度改善 例が 3 例, 軽度改善例は 2 例, 不変例も 2 例で, 悪化 した例もなかった。追跡調査期間と症状改善との間に, 相関はなかった。すなわち手術により症状の悪化はな く進行も認められないものの劇的に改善する例もなかっ た. MRIにて follow し得たものに限って言えばす べて脊髄の萎縮は残っており, この事が症状改善が思 わしくない原因であると考えている.

\section{結語}

仚髄くも膜囊腫の手術成績を報告した.くも膜囊腫 は長年にわたり絶えず拍動を続けながら増大し脊髄を 圧迫し続けるため脊䯣の萎縮が起こり, 手術による劇 的な症状の改善は期待できない. しかしながら症状が 緩徐進行性であり脊䯣萎縮が認められることを考える と, 早期診断による早期の手術的治療が望ましい.

\section{参考 文 献}

1) Benini, A.: Chronic circumscribed adhesive and cystic spinal leptomeningitis. Surg Neurol, $1: 223-228$, 1973.

2) Enzmann, D. R. et al.: Cerebrospional fluid pulsa- 
tion; Benefits and pitfall in MR imaging. Radiology, $161: 773-778,1986$.

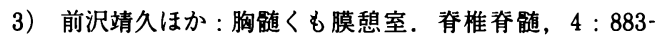
839, 1991.

4) 松尾 哲ほか: 脊䯣硬膜内くも膜哄腫の一例. 整外と 災外, $36: 226-229,1987$.

5) Nabors, M.W. et al.: Updated assessment and current classification of spinal meningial cysts. J Neurosurg, $68: 366-377,1988$.

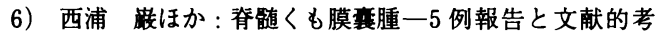
察. 脳外, $12: 1385-1392,1984$.

7）尾崎文教ほか: 脊䯣くも膜衰腫. 脊椎脊䯣, $2: 75-81$, 1989.

8) Perret, G. et al.: Diagnosis and treatment of intradural arachnoid cyst of thoracic spine. Radio- logy, $79: 425-429,1962$.

9) Raja, I. A. et al.: Congenital spinal arachnoid cysts. J Neurol Neurosurg Psychiatry, 33 : 105-110, 1970.

10) Spiller, W.G. et al.: A case of intradural spinal cyst with operation and recovery; with a brief report of eleven cases of tumor of the spinal cord or spinal columm. Trans Coll Physicians Phila, 25 : 1-18, 1903.

11）内野 晃ほか: 脊䯣くも膜襄胞の MRI. 臨放, 35 : 411-414, 1990.

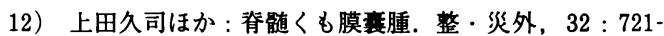
$727,1989$.

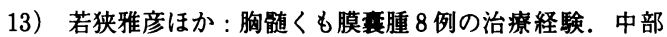
整災誌, $33: 1900-1902,1990$. 